\title{
Two new synonyms and a species reinstated in Phoradendron Nuttall ${\text { (Viscaceae })^{1}}^{1}$
}

\author{
Claudenir Simões Caires² and Carolyn Elinore Barnes Proença ${ }^{3,4}$
}

Received: 16/03/2006. Accepted: 26/10/2006

\begin{abstract}
RESUMO - (Dois novos sinônimos e uma espécie restabelecida em Phoradendron Nuttall (Viscaceae)). Três mudanças taxonômicas são propostas baseadas em coletas intensivas de Viscaceae no Distrito Federal, Brasil. Phoradendron andersonii Rizzini, previamente considerada sinônimo de P. perrottetii (DC.) Eichler é restabelecida baseada na seguinte combinação de caracteres: entrenós jovens compressos com ângulos agudos na porção distal, espigas curtas com até $2,5 \mathrm{~cm}$ de comprimento, artículos mistos de flores masculinas e femininas, flores bisseriadas e frutos amarelo-pardacentos. Phoradendron irwinianum Kuijt é sinonimizada sob P. apiciflorum Rizzini, espécie previamente conhecida apenas do tipo do oeste de Minas Gerais. Por fim a localização do material tipo de P. brachyklados Rizzini, incorretamente citado no protólogo, resulta em proposta para que esta espécie seja tratada como um sinônimo de $P$. hexastichum (DC.) Grisebach.
\end{abstract}

Palavras-chave: Cerrado, Distrito Federal, hemiparasita, taxonomia

\begin{abstract}
Two new synonyms and a species reinstated in Phoradendron Nuttall (Viscaceae)). Three taxonomic changes are proposed based on intensive collecting of Viscaceae within the Distrito Federal, Brazil. Phoradendron andersonii Rizzini, previously a synonym of $P$. perrottetii (DC.) Eichler is reinstated based on the following combination of characters: young internodes compressed with sharp angles at the distal ends, short spikes to $2.5 \mathrm{~cm}$ long, articles with intermixed male and female flowers, biseriate flowers, and dirty yellow fruits. Phoradendron irwinianum Kuijt is synonymized under P. apiciflorum Rizzini, previously known only from the type from western Minas Gerais. Finding of the type collection of $P$. brachyklados Rizzini, incorrectly quoted in the protologue, led to the synonymization proposal of this species under P. hexastichum (DC.) Grisebach.
\end{abstract}

Key words: Cerrado, Distrito Federal, hemiparasite, taxonomy

\section{Introduction}

A detailed study of the Viscaceae of the Distrito Federal, Brazil, was undertaken between 2001 and 2003. Eighteen of the 21 species were observed in the field and collected together with their hosts, and nomenclatural types or their images were studied (Caires \& Proença 2005).

Since the Flora do Distrito Federal precludes publication of new synonyms or detailed taxonomic discussions elsewhere, two new synonymizations are presented, and one former synonym reinstated in this paper. These proposals are related to previous Kuijt (2003) statements, which are discussed below: 1) the synonimyzation of $P$. andersonii Rizzini under P. perrottetti (DC.) Eichler; 2) the description of
P. irwinianum Kuijt; and 3) the status of nomen dubium attributed to $P$. brachyklados Rizzini.

\section{Material and methods}

Specimens were collected in Cerrado, Cerradão, Mata ciliar, Mata de galeria and Mata mesofítica. Phoradendron collections deposited in the CEN, IBGE, HEPH, RB and UB herbaria, including types, were also studied. Complete lists of examined material are available in Caires \& Proença (2005). Images available at the New York Botanical Garden (2002) and National Herbarium Nederland (2002) sites were also examined.

Scientific names which appear between square brackets after cited names refer to the name accepted

\footnotetext{
Part of the first Author's M. Sc. Thesis

2 Universidade Federal de Mato Grosso do Sul (Departamento de Biociências, Campus Aquidauana, C. Postal 135, 79200-000 Aquidauana, MS, Brasil.

3 Departamento de Botânica, Universidade de Brasília, C. Postal 4457, 70919-970 Brasília, DF, Brazil

4 Corresponding author: cproenca@unb.br, cscaires@hotmail.com
} 
by Kuijt (2003). Complete lists of synonyms for the species are also to be found in Kuijt (2003).

\section{Results and discussion}

1. Phoradendron andersonii Rizzini, Arq. Jard. Bot. Rio de Janeiro 24: 29, fig. 6.3. 1980. "Phoradendron andersoni”. Type: BRAZIL. Goiás: cerrado ca. 8 $\mathrm{km}$ south of Niquelândia, 750m, 23/I/1972, Irwin et al. 34866 (RB!, Holotype; LEA, NY, UB!, Isotypes).

Rizzini (1980) noted that this species was related to $P$. cerinocarpo Wright ex Trel. $[=P$. anceps (Spreng.) M. Gómez] and $P$. carinato Trel. $[=P$. bilineatum $\mathrm{Urb}$.]. In the field, it is very similar to both $P$. lanceolato-ellipticum (Pohl) Eichler [=P. interruptum (Jackson) DC.] and P. perrottetii (DC.) Eichler, particularly in leaf shape. This similarity led Kuijt (2003) to relegate $P$. andersonii to the synonymy of $P$. perrottetii, noting that he had seen specimens of $P$. perrottetii with inflorescences which were similar to those of $P$. andersonii. However, Kuijt (2003) noted this as a provisional synonym, indicating he did not consider the case closed. We have not been unable to examine the same $P$. perrottetii specimens cited by Kuijt, but during our study nine new collections of $P$. andersonii and 26 of $P$. perrottetii were made, besides field observations of both species. These taxa are clearly distinct, their differences summarized in Table 1.

Based on these differences, and having analyzed the types of $P$. andersonii and $P$. perrottetii, we conclude that $P$. andersonii is distinct from $P$. perrottetii and should be maintained.

Selected Material (P. andersonii - see Caires \& Proença 2005 for complete list of examined material): BRAZIL. Distrito Federal: Bacia do rio São Bartolomeu, 4/XII/1979, Heringer et al. 2868 (IBGE); APA de Cafuringa, 15³5' S, 47 ${ }^{\circ} 54^{\prime} \mathrm{W}, 881 \mathrm{~m}$, 2/IV/2002, Caires \& Mendes 102 (UB); Parque Nacional de Brasília, 1543'S, 48 04'W, 1247m, 11/VI/2002, Caires \& Mendes 158 (UB). Goiás: Chapada dos Veadeiros, $15 \mathrm{~km}$ south of São João da Aliança, 1120m, forest edge, 21/III/1973, Anderson 7510 (UB, paratype of $P$. andersonii).

Selected Material ( $P$. perrottetii - see Caires \& Proença 2005 for complete list of examined material): BRAZIL. Distrito Federal: Almécegas, APA de Cafuringa, $15^{\circ} 32^{\prime} \mathrm{S}, 48^{\circ} 10^{\prime} \mathrm{W}, 900 \mathrm{~m}$, 26/III/2002, Caires \& Mendes 79 (UB); Bacia do rio São Bartolomeu, 4/XII/1979, Heringer et al. 2860
(IBGE); Parque do Gama, 1602'S, 48 $03^{\circ} \mathrm{W}, 1044 \mathrm{~m}$, 23/X/2001, Caires \& Mendes 16 (UB); Córrego Vicente Pires-EPTG, $15^{\circ} 48^{\prime} \mathrm{S}, 4^{\circ} 00^{\prime} \mathrm{W}, 1094 \mathrm{~m}$, 19/III/2002, Caires et al. 63(UB). FRENCH GUIANA. Without locality, Perrottet 228 (Microfiche of type of $P$. perrottetii: G-DC).

2. Phoradendron apiciflorum Rizzini, Rev. Fac. Agron. (Maracay) 8(3): 86. 1975. Type: BRAZIL. Minas Gerais: cerrado ca. $4 \mathrm{~km} \mathrm{~N}$. de Patrocínio, 31/I/1970, Irwin et al. 25724 (RB, Holotype; COL, F, UB!, US, Isotypes).

Phoradendron irwinianum Kuijt, Syst. Bot. Monogr. 66: 248. 2003. Type: BRAZIL. Distrito Federal: 5 km oeste de Formosa, estrada para Brasília, mata de galeria, $900 \mathrm{~m}$, 8/X/1965, Irwin et al. 9060 (F, Holotype; NY, RB!, UB!, US, Isotypes). syn. nov.

During our study four collections of $P$. apiciflorum were made. In our opinion, these collections and the types of $P$. apiciflorum and $P$. irwinianum belong to a single species, characterized by being a monoecious plants, with large, imperfectly acrodromous, coriaceous leaves up to $10 \mathrm{~cm}$ long, 1-2(-9) spikes per leaf axil, short spikes 1,3-4 cm long, with 4 articles, the articles with 6-10(-14) biseriate flowers, the male flowers dispersed throughout the articles, and ovoid, yellowgreen fruits with closed tepals. Geographically, the Distrito Federal population is c. $300 \mathrm{~km}$ NNW of the type locality of $P$. apiciflorum, but the highland habitat is more or less continuous between the Distrito Federal highlands and the Serra de Paracatu, Minas Gerais. Furthermore, one of the specimens of $P$. apiciflorum (Heringer et al. 2927) cited by Kuijt (2003) and the type of $P$. irwinianum were found growing on Roupala sp. (Proteaceae). Within the Distrito Federal, Roupala montana Aubl. is common in cerrado (woodland savannas), while possibly distinct Roupala brasiliensis Klotzsch grows in mata de galeria (gallery forests); neither species was found as host to any other species of Viscaceae in the Distrito Federal (Caires \& Proença, unpublished data).

Phoradendron apiciflorum Rizzini is very similar to $P$. coriaceum Mart. ex Eichler, found in the Brazilian states of Amazonas, Piauí, Alagoas, Bahia, Minas Gerais, Rio de Janeiro, Paraná, and Rio Grande do Sul, and Argentina (Kuijt 2003). Therefore, with additional collections and more detailed studies, $P$. apiciflorum and $P$. irwinianum may become synonyms of $P$. coriaceum.

Selected Material (see Caires \& Proença 2005 for complete list of examined material): BRAZIL. 
Table 1. Contrasting characters distinguishing P. andersonii Rizzini and P. perrottetii (DC.) Eichler.

\begin{tabular}{|c|c|c|}
\hline Characters & $P$. andersonii (15 collections) & P. perrottetii (39 collections) \\
\hline Shape of young internodes & Compressed, with sharp edges, at distal ends & Perfectly cylindrical at distal ends \\
\hline Length of spikes & Short (maximum 2,5 cm) & Long (maximum 7,5 cm) \\
\hline Type of spike (Kuijt 1959 system) & Biseriate $(1 \mathrm{~A})$ & Triseriate $(1 \mathrm{~B})$ \\
\hline Flower sex in an article & Male and female intermixed & Either only male or only female \\
\hline Number of flowers per article & Few (maximum 14) & $\begin{array}{l}\text { Many (maximum } 620^{\circ} \text { articles and } 40 \\
+ \text { articles) }\end{array}$ \\
\hline Fruit colour & Dirty yellow & White or cream \\
\hline Host selectivity & $\begin{array}{l}\text { Generalist growing on Asteraceae, Bignoniaceae, } \\
\text { Loranthaceae, Malpighiaceae, Melastomataceae*, } \\
\text { Meliaceae, Myrtaceae, Rubiaceae* and } \\
\text { Vochysiaceae* }\end{array}$ & $\begin{array}{l}\text { Selective growing on Anacardiaceae } \\
\text { (mostly on Tapirira guianensis Aubl.), } \\
\text { but also in frequently growing on } \\
\text { Fabaceae, Myrtaceae, Sapindaceae and } \\
\text { Sapotaceae }\end{array}$ \\
\hline
\end{tabular}

* Fide Kuijt (2003); all others collected during this study

Distrito Federal: $5 \mathrm{~km}$ W of Formosa, road to Brasília, gallery forest, $900 \mathrm{~m}, 8 / \mathrm{X} / 1965$, Irwin et al. 9060 (RB, UB); DF 180 Fazenda S.D.V.S.A. 098-02. APA de Cafuringa, $15^{\circ} 33^{\prime} \mathrm{S}, 4^{\circ} 11^{\prime} \mathrm{O}, 974 \mathrm{~m}, 25 / \mathrm{VI} / 2002$, Caires et al. 171 (UB); Fazenda Campina Verde, APA de Cafuringa, 11/VII/2002, Caires \& Ramalho 181 (UB); Gama, Próximo a Embrapa-CNPH, $15^{\circ} 56^{\prime} \mathrm{S}$, $48^{\circ} 08^{\prime} \mathrm{O}, 1003 \mathrm{~m}, 18 / \mathrm{XII} / 2002$, Caires et al. 276 (UB). Minas Gerais: cerrado ca. $4 \mathrm{~km} \mathrm{~N}$ of Patrocínio, 31/I/1970, Irwin et al. 25724 (UB).

3. Phoradendron hexastichum (DC.) Griseb., Fl. Brit. W. I. 313. 1860. Type: CUBA. La Habana: Havana, 1825, de la Ossa s.n. (G-DC, Holotype; Microfiche, G-DC!, photos: F Negative no. 33514, Trelease, 1916, Fig. 200a).

Phoradendron brachyklados Rizzini, Ernstia 32: 2. 1985. Type: BRAZIL. Distrito Federal: Brasília, 23/X/1979, Heringer et al. 2600 (IBGE!, Holotype; RB!, Isotype). syn. nov.

Kuijt (2003) considered P. brachyklados as a nomen dubium, stating that he had been unable to find the type. It is possible that the type was not located by Kuijt due to an error made by Rizzini (1985) in the protologue of $P$. brachyklados: he omited the collector's name, citing only the herbarium followed by the collection number, as if this were the specimen accession number, rather than the collector's number.

Phoradendron bachyklados Rizzini is proposed as yet another synonym, in addition to the eight synonyms accepted by Kuijt (2003) for $P$. hexastichum. Comparing descriptions, illustrations, material examined by Kuijt (2003) and our own collections with the type of $P$. brachyklados, we concluded that this species is a perfect match for the "narrow-leaved South American variant" cited by Kuijt (2003).

Examined Material: BRAZIL. Distrito Federal: Bacia do rio São Bartolomeu, 22/X/1980, Heringer et al. 5597 (IBGE); Córrego Vicente Pires, setor Industrial, 12/VII/1966, Ramos 6615 (UB); EPTG, Córrego Vicente Pires, $15^{\circ} 48^{\prime} \mathrm{S}, 48^{\circ} 00^{\prime} \mathrm{W}, 1082 \mathrm{~m}$, 19/III/2002, Caires et al. 65 (UB); Fazenda Dois Irmãos, APA de Cafuringa, 153' 'S, 48º6' W, 1225 m, 21/VIII/2002, Caires et al. 209 (UB); Núcleo Rural Tabatinga, Fazenda Sete Veredas, $15^{\circ} 43^{\prime} \mathrm{S}, 47^{\circ} 29^{\prime} \mathrm{W}$, 927 m, 6/VIII/2002, Caires et al. 187 (UB); Reserva Ecológica do IBGE (RECOR), $15^{\circ} 57^{\prime} \mathrm{S}, 47^{\circ} 52^{\prime} \mathrm{W}$, 2/X/1989, Azevedo et al. 364 (IBGE).

\section{Acknowledgements}

The authors thank C.L. Ramalho and V.C. Mendes for assistance in the field. C.S. Caires thanks CAPES (Coordenação de Aperfeiçoamento de Pessoal de Nível Superior) for funding an M. Sc. fellowship to the Programa de Pós-graduação em Botânica, Universidade de Brasília.

\section{References}

Caires, C.S. \& Proença, C.E.B. 2005. Viscaceae. Pp. 41-76. In: T.B. Cavalcanti \& A.E. Ramos (eds.). Flora do Distrito Federal, Brasil v. 4. Brasília, Embrapa Recursos Genéticos e Biotecnologia.

Kuijt, J. 1959. A study of heterophylly and inflorescence structure in Dendrophthora and Phoradendron (Loranthaceae). Acta Botanica Neerlandica 8: 506-546. 
Kuijt, J. 2003. Monograph of Phoradendron (Viscaceae). Systematic Botany Monographs 66: 1-643.

National Herbarium Nederland. 2002. http:// www.nationaalherbarium.nl/virtual. (Accessed May 2003).

New York Botanical Garden. Vascular Plant Types Catalogue.
2002. http://sciweb.nybg.org/science2/hcol/vasc/ index.asp. (Accessed May 2003).

Rizzini, C.T. 1980. Loranthaceae of the Central Brazil. Arquivos do Jardim Botânico do Rio de Janeiro 24: 19-50.

Rizzini, C.T. 1985. New or less known Loranthaceae from Brazil and Venezuela. Ernstia 32: 1-16. 